\title{
PedAgógus eTIKAI KÓdeXEK Vizsgálata - AZ ELSŐ LÉPÉS
}

\section{Horváth Attila}

a Debreceni Egyetem Bölcsészettudományi Karának hallgatója horatt37@hotmail.com

\begin{abstract}
Ha a pedagógus etikával, vagyis a szaketikák egyik képviselöjével kívánunk foglalkozni, a vizsgálat rögtön nehézségekbe ütközik. Nem csak a pedagógus etika hazai szakirodalma mondható csekélynek, de ugyanez a megállapitás érvényes az általános szaketikákkal foglalkozó müvekre is. Súlyos hiányosság a szakirodalmi kidolgozatlanság, hiszen az érvényben lévö pedagógus etikai kódex(ek) vizsgálatához elengedhetetlen az elméleti háttér ismerete, ami feltehetöleg nem csak az adott szakma megállapitásaiból táplálkozik, hanem egyéb szakmák etikai diskurzusaiból is, melyek már sokkal régebben vizsgálják saját tevékenységük erkölcsi aspektusait.
\end{abstract}

\section{A pedagógus etika vizsgálatának nehézségei, a szaketikák, kódexek sajátosságai}

A szakirodalom első olvasásakor zavaró tényezőt jelenthet, hogy a szakmai etika kifejezés mellett több vonatkoztatható szinonimát is találhatunk a különféle munkákban - ezzel nehezítve a fogalom megértését. Megjelenik a hivatásetika (Zrinszky, 1988), vagy a szaketika (Hajdú, 1986; Bertók, 2009) kifejezés is, melyek mögött azonban lényegüket tekintve ugyanazzal a jelentéssel kell számolnunk.

Kiss a következőképpen határozza meg a szaketikák lényegét: „Az etikán belül a szaketikák vagy szakmai etikák különleges helyet foglalnak el, megvilágítják egy szakma elméletének és gyakorlatának erkölcsi, etikai aspektusait, egy foglalkozás, egy hivatás körében uralkodó erkölcsi és magatartási szabályokat." (Kiss, 2006. 5. o.). Ugyanez tömörebb megfogalmazásban: „A szaketika fogalma egy szakmához kötődik, ahogy a neve is mutatja, egy szakmának az etikai elveit és az etikának a szakmai relációkban való megjelenését jelenti." (Bertók, 2009. 16. o.). Továbbá egy rendszerváltás előtti gondolat a szaketikákról: „A szaketikák fö feladata az, hogy az egyes foglalkozások, célrendszerének, a foglalkozási csoportok tagjainak napi gyakorlatában fennálló objektív viszonyoknak, az adott munkára, munkahelyi közösségtípusokra jellemző erkölcsi állapotoknak, kapcsolatoknak, konfliktusoknak, a feltárása révén rögzítsék a munkamegosztásban megközelítőleg azonos helyet elfoglaló embercsoportok iránti speciális erkölcsi elvárásokat" (Hajdú, 1986. 7. o.). A szaketikák, szakmai etikák, vagy más néven hivatásetikák részben az általános etikára 
épülnek, azonban kiegészülnek olyan erkölcsi megfontolásokkal, amelyek az adott szakma speciális tevékenységéből adódnak.

A fogalom megmagyarázásához azonban bizonytalanság kapcsolódik, mely abban a polémiában nyilvánul meg, hogy egyáltalán szükséges-e az általános etikától ily módon megkülönböztetett speciális etika. Meglepö módon ez a bizonytalanság a szaketikák lényegének megértéséhez is közelebb visz. Kiss is megemlíti, hogy ,az etikával foglalkozók véleménye megoszlik abban a tekintetben, hogy szükség van-e minden szakma esetében a szaketikával való foglalkozásra, az etikai kódex kidolgozására vagy egy szakma esetében a ki nem dolgozottság elvi természetủ vagy csupán a még nem eléggé elörehaladott professzionalizálódás jele." A kérdés tehát adott: Mely szakmák esetében van tétje a szakmai etika kidolgozásának? Kiss megjegyzi (Kiss, 2006. 5. o.): vannak olyan vélemények, amelyek szerint nem szükséges minden szakmának saját szakmai etika. Azon gondolatok ismertetéséből, amelyek a szakmai etika létjogosultságát igyekszenek bizonyítani, kiderül, hogy leginkább azoknak a szakmáknak van szüksége szakmai etikára, amelyek hivatásnak tekinthetőek. Hivatásról pedig leginkább akkor beszélünk, amikor a munka során végzett tevékenység célja mások szolgálata, vagy másképpen kifejezve: azok a szakmák, melynek fókuszában az ember áll. E kritériumon kívül azokat a szakmákat tekinthetjük hivatásnak, amelyeknél „egy szakma vagy szakmai közösség iránti érzelmileg színezett, értékvezérelt tudatos és felelös elkötelezettség" van jelen (Kiss, 2006. 5. o.). Egy ilyen értékvezérelt elkötelezettség esetében azonban nem csak a szakma, hanem a társadalom, a nyilvánosság formáló ereje is elkerülhetetlen.

Felvetődhet azonban a kérdés: Mégis milyen tétje van a szaketikáknak az adott szakmák életében? Elsőként érdemes megemlíteni, hogy a szakmai etika és a szakmai etikai kódexek kimunkálását a professzionalizáció lényeges részének tekintik, valamint az alá- és fölérendeltségből származó konfliktusok kezelésében is érdemleges szerepet tulajdonítanak ezeknek az etikáknak (Kiss, 2006. 6. o.). A teljes képhez továbbá érdemes idézni Kiss felsorolását, amely a szakmai etikától remélhető folyamatokat veszi számba:

- „megismerhetjük a szakma gyakorlatának etikai nézőpontból vizsgált aspektusait, közösségi érdekeit,

- $\quad$ ez növeli a szakmai kultúrát, önismeretet, amelynek a szakmai erkölcs és erkölcsi vizsgálódás szerves része,

- normatív jellege által szabályozza a szakmai viselkedést, ezzel külső és belső „védelmi funkciót” lát el, elsősorban a szakmai vétségek elkövetését csökkenti,

- elősegíti a magasabb minőségú szakmai szolgálat nyújtását,

- növeli a szakmai hatékonyságot és a presztízst,

- növeli a szakma iránti bizalmat.” (Kiss, 2006. 5. o.) 
Eddig csupán a szaketikáról volt szó, azonban nem tértünk ki az etika és a kódex viszonyára. Az etikai kódexeket a közvetlenül az etikából származó normák, szabályok írásban való rögzítéseként foghatjuk fel. Ennek analógiájára a szakmai etikák és a szakmai etikai kódexek viszonya is ugyanígy leírható. Bertók két kódexfajtát említ a szakmai etikai kódexekkel kapcsolatban: az előíró, valamint a leíró jellegü kódexeket. Különbség köztük, hogy az előíró kódexek előírják a kívánatos viselkedést, a leíró jellegü kódexek a gyakorlattá vált működés elemi részeit igyekszenek rögzíteni, utóbbiban tehát egy állapot rögzítéséröl van szó (Bertók, 2009. 15. o.). Fontos azonban megjegyezni, hogy ahogyan az előbbi magyarázatból is jól látszik a kódextípusok definiálása még nem elég kifinomult, a két fajta leírása egyértelmúen tautologikus. Magukról a kódexekről, azok formai, tartalmi és egyéb kritériumairól, gyakorlati relevanciájukról nem találunk tudományos igényü írást.

Mielött a kódexek vizsgálatában elmerülnénk, a már említett etika-kódex összefüggést figyelembe véve vizsgáljuk meg, hogyan jutottak kifejezésre a pedagógus etikát tárgyaló müvekben az eddig ismertetett megállapítások, mennyiben mutathatók ki egyezések vagy eltérések, ezáltal képet alkotva szakmánk, de helyesebben mondva hivatásunk etikájáról.

\section{Van-e létjogosultsága a pedagógusetikának?}

A bevezetőben is említett kérdéssel több munkában is találkozunk. Zrinszky csoportokra osztja a kérdéssel kapcsolatos véleményeket. Ekkor megállapítja, hogy a pedagógus etika létének megkérdőjelezői három különböző indokra hivatkoznak:

1. Az egyik ilyen vélemény, hogy egy pedagógus etika szükségtelen, mivel „az etika nem differenciálódik hivatáskörönként”, tehát az általános etikán kívül nincs szükség speciális vonatkozású normarendszerre, hiszen az általános etika minden erkölcsi mozzanat értelmezéséhez megfelelö.

2. A másik tagadó álláspont szerint azért nincs szükség ilyen speciális etikára, mert a szakma sajátos erkölcsi problémái tulajdonképpen egyben szakmai jellegúek is, amelyek már a társadalmi elvárásokban és jogilag is szabályozva vannak.

3. A harmadik és egyben az utolsó szembehelyezkedő álláspont szerint azért nincs szükség pedagógus etikára, mert még egy rendkívül pontosan kidolgozott pedagógus etika is csak csekély szerepet játszhat a valóságos cselekvésben, tevékenységben (Zrinszky, 1988. 4-6. o.).

Valójában azonban az általános erkölcsi normák között is eltéréseket figyelhetünk tértől, időtől, társadalmi folyamatoktól függően (Bábosik, 2001. 12. o.). Mindez azonban nem a teljes különállást jelenti. A szakmai etikák - így a pedagógus etika is - az általános etikától függenek, azonban speciális gyakorlati helyzeteinek köszönhetően bizonyos mértékben el is térhetnek az általános etikáktól (Zrinszky, 
1988. 8. o.). Továbbá könnyen belátható, hogy az emberközi viszonylatokkal szorosabban kapcsolatban álló, valamint ezek közül is az alkotó tevékenységet igénylő szakmák esetében nem elegendő az állandósult rutintevékenység, még ha azok szigorú szabályokra is épülnek (Zrinszky, 1988. 9. o.). A pedagógusetika ellen támasztott ellenérvek közül csupán az utolsóra nem tudunk megnyugtató választ adni, mely abból adódik, hogy gyakorlati hatásának vizsgálatáról mindeddig nincs tudomásunk. Éppen ezért e kutatás jövőbeli célja a pedagógusok között felmérni az adott iskolák kódexeinek gyakorlati relevanciáját.

Az ellenérvekkel szembeni direkt polemizáláson túl sokkal hasznosabb lehet, ha azokat a megállapításokat vesszük sorra, melyek a hazai szakirodalomban tünnek fel. Elsőként fontos megjegyezni, hogy a szakirodalom tételei közül több is idézi azt a megállapítást, mely szerint minden olyan szakmának szüksége van hivatásetikára melynek tevékenységének központjában az ember áll. Hajdú véleménye szerint az „olyan foglalkozásoknál, melyeknél a munka objektuma az ember, ahol a tevékenység az emberre irányul, közvetlenül az emberért folyik", nem elegendőek az általános munkaerkölcsi normák (Hajdú, 1986. 9. o.). Zrinszky is beemeli N. J. Jusmanova megállapítását, aki szerint azoknak a hivatásoknak van szüksége saját etikára, ahol „, a hivatás-tevékenység objektuma az ember.” (Zrinszky, 1988. 8. o.). A rendszerváltás után író Bertók is magáévá teszi a megállapítást: „Azokon a területeken, ahol az ember-ember közötti kapcsolat fennáll és közvetlen, ott fontos társadalmi biztosíték a szaketikák létrejötte" (Bertók, 2009. 14. o.). Egyértelmü tehát, hogy a szakirodalom több tétele szerint is, a pedagógus etika létrejöttét a szakma egy olyan tulajdonsága adja, mely elválasztja több munkakörtől is: az ember-ember közötti kapcsolat. Láthatjuk, hogy az első elemi indoklás megfelel a bevezetöben leírt szaketikákra vonatkozó kritériumnak. Természetesen azonban több olyan szakma is létezik, mely pont ebben a minőségében hasonlít leginkább a pedagógus szakmához. Hasonló módon az ember áll a fókuszban az orvos-, az ügyvéd-, a pszichológus-, a szociális munkás stb. szakmákban. Nem is kerülte el a már említett szerzők figyelmét ez a tény, ugyanis többször találhatunk utalást ezekre a hasonlóságokra. Erre világít rá Hajdú is, amikor kimondja, hogy „A társadalom a fejlett erkölcsiséget, a feltétlen felelősségtudatot az orvos a pedagógus, a jogász, a javak és emberek felett diszponáló vezetők stb. szakmai megfelelési kritériumaiként tartják számon." (Hajdú, 1986. 9. o.). Zrinszky idézi a Pedagógiai Tudományok Akadémiájának 1968-as határozatát, mely szerint a tanári szakma ugyanúgy ,hivatásetikát követel" mint az orvosi vagy a bírói szakma (Zrinszky, 1988. 8. o.). A két idézett szövegrészletből jól látható, hogy leginkább a jogi és az orvosi szakmák kerültek kiemelésre a hasonlóság szempontjából. Ehhez képest elörelépést jelent Bertók megállapítása, aki már az üzleti etikát is beemeli a sorba, ugyanis etikai szempontból hasonló kapcsolatot feltételez az ügyfél és az ügyvezető között, mint a tanár és diák viszonylatban (Bertók, 2009. 14. o.). Már a pedagógus etikai kódexet kísérő egyik tanulmányban is megjelenik ez a fajta felsorolás, sőt részben ismerteti is a külön- 
böző kiválasztott szakmák etikai kódexét, azonban, ahogyan írja: „Az elemzés elsősorban a kódexek tartalmára, valamint a müködtetés körülményeire terjed ki. Nem célunk összehasonlítani, minősíteni a kódexek tartalmát." (Hoffman, 2003. 56. o.). Különösen nagy jelentősége lenne pedig egy ilyen összehasonlító eljárásnak, ugyanis az előbb említett tanulmányban már az újságírói etikai kódex is példaként van állítva a pedagógus szakma számára, miközben a két szakma közötti eltérés első látásra igen jelentős. Ahhoz azonban, hogy a valódi véleményalkotás megtörténhessen, szükséges lenne a már említett összehasonlítás, ugyanis a már elkészült etikai kódexeken keresztül rendkívül fontos és elengedhetetlen adatok lennének kinyerhetők a pedagógus etika számára.

Bertóknál (Bertók, 2009. 14. o.) és Hajdúnál (Hajdú, 1986. 9. o.) is megjelenik továbbá a feltételezett társadalmi igény az iránt, hogy a pedagógusok rendelkezzenek morális szabályokkal. Az ember-ember kapcsolathoz hasonlóan a társadalmi igény jelzése is megfelel a Kiss megállapításának, mely szerint a közvélemény, a laikusok is formálják a pedagógus etikát (Kiss, 2006. 5. o.).

A szakma sajátságaiból származó speciális igény is megfogalmazódik. Ezt fejezi ki például Szathmáry véleménye is, amikor azt mondja, hogy a pedagógus etika létrehozásának egyetlen oka lehet, mégpedig, „hogy az általános érvényü etikai normák pedagógiai, tehát speciális vonatkozásban fokozott jelentőségüek”. Ennek oka pedig Szathmáry szerint az lehet, hogy a pedagógusoknak nem csak be kell tartaniuk ezeket a normákat, hanem nevelni is kell erre a diákokat. Így tehát a tanárok nevelői feladata hívhatja életre a pedagógus etikát Szathmáry szerint (Szathmáry, 1975. 6. o.).

Megjelenik továbbá a szakmai etikai kódex presztízsre gyakorolt hatása is, amikor Gábor aggódva jegyzi meg, hogy a pedagóguspálya presztízsével valami baj van (Gábor, 1988. 46. o.). Majd, amikor a megoldást keresi, megállapítja, hogy „márpedig bizonyos, hogy a jogtalan támadásokkal szemben, a pálya presztízsének védelmében csak az egységes tantestület léphet föl eredményesen." (Gábor, 1988. 51. o.). Bár nincs világosan kifejtve, de a munka címét tekintve, valamint a központi témát és a többi véleményét összeolvasva úgy tünik, hogy az egységes tantestület kialakulását a pedagógus etikán keresztül lehet elérni. Ennél sokkal világosabban fejezi ki Szathmáry ugyanezt a gondolatot, mikor azt mondja, hogy: „A jó testületnek tehát nem személyiség-alkati és módszerbeli egységre van szüksége, hanem etikai egységre, amelyben a testület tagja az igazságosság és méltányosság, valamint a megbecsülés és a szeretet értékeiben bővelkedve közelednek és alkalmazkodnak egymáshoz. Ez az etika szolgálja a társadalmi és pedagógiai érdeket a legmagasabb szinten." (Szathmáry, 1975. 6. o.). Szathmárynál tulajdonképpen a szervezeti, tantestületi egység gondolata jelenik meg, ami összekapcsolódott a presztízs védelmével. Itt megemlíthető továbbá, hogy az 1995-ben elfogadott etikai kódex kísérö tanulmányaiban is megjelenik a tanári pálya presztízscsökkenésének a gon- 
dolata, valamint, hogy az etikai kódex által ez a folyamat kedvezőbb irányt vehet. (Hoffman, 1997. 11-12. o.).

A pedagógusetika indoklásakor megjelennek a képzési hiányosságok is. Erről ír Gábor is, amikor azt mondja, hogy a tanárnak készülő jelölteket is nevelni kell, hogy „nevelői személyiségük” kibontakozhasson (Gábor, 1988. 45. o.). Ennél világosabban jelenik meg Hoffmannál ugyanez a gondolat, sőt továbblépve összekapcsolja az etika és a pedagógusképzés problémáit a hivatástudat kialakulásával: „Nagyrészt hiányoznak, vagy alacsony hatásfokuknál fogva tökéletesen háttérbe szorulnak az olyan stúdiumok, amelyek a szakmai elkötelezettség, a hivatástudat formálását szolgálnák. Alig van olyan pedagógusképző intézmény, ahol elmélyülten foglalkoznának etikával, hangsúlyozottan pedagógusetikával." (Hoffman, 1997. 9-10. o.). Ez a megállapítás nincs azonban összhangban a szakmai etikai kódexek jellemzőivel, így ennek felvetése egyelöre kérdéses.

Zrinszky érveket és ellenérveket is hoz, majd megállapítja, „hogy a létjogosultság elégséges indokát több kritérium együttese szolgáltatja.”. (Zrinszky, 1988. 9. o.) Összegyüjtve az addigi véleményeket kimondja, hogy korábban az indoklás leginkább kétféle volt. Vagy azzal indokolták, „hogy a nevelőnek fokozottan, példaszerüen erkölcsösnek kell lennie”, vagy azzal, „hogy ezen a pályán olyan sajátos emberi kapcsolatok létesülnek, melyek az általános etikából levezethetetlen különös erkölcstant kívánnak meg, számos szerző pedig mindkét indokot hangsúlyozza." (Zrinszky, 1988. 7. o.). Zrinszky azt mondja, hogy a tanárok nevelö feladata, a sajátos emberközi viszonylatok, a foglalkozási pozícióból következő viszonyok és az ezekből következő konfliktusos helyzetek együtt teszik szükségessé a pedagógus etikai kódexet (Zrinszky, 1988. 9-10. o.). A szakmai kultúra, az erkölcsi problémák vizsgálata és az önismeret is megjelenik Zrinszkynél, amikor idézi Hajdú megállapítását, mely szerint „A jó tanár alapvetően önmaga produktuma.”. Zrinszky ehhez hozzáfúzi, hogy itt nem csak arról van szó, hogy egy erkölcsi kódexre támaszkodva a tanár megfelelő megoldásokat talál, hanem, hogy „gyakorlata folyamatában önmagát, mint erkölcsi személyiséget kontrollálja és fejleszti” (Zrinszky, 1988. 39. o.). Látható tehát, hogy a tanár személyiségével kapcsolatosan az intraperszonális, valamint a különbözö emberközi viszonylatok miatt az interperszonális szinten is normákat kell megállapítani Zrinszky szerint.

A pedagógusetika iránt tehát egyértelmüen jelezett az igény, az indoklások megegyeznek a szakmai etikáktól várható haszonnal, azonban a különböző elemek csak egy ilyen összefoglalásban tünnek egymásra épülő, jól átgondolt koncepciónak, valójában a művekben elszórtan szereplö gondolatokról van szó, nincsenek olyan egységesített formában, mint ahogyan azt Kissnél, a várható hasznokat tárgyaló felsorolásában láthatjuk. Itt érdemes megállni és megvizsgálni, vajon miért nem rendeződtek teljes, kiforrott egységbe a pedagógusetikával kapcsolatos megállapítások. A válasz egyik részét az 1988-ban íródott Zrinszky kötet hátsó borítóján olvashatjuk: „A pedagógusetika kérdéseinek nincs szakmai irodalma. Sorozatunk 
arra vállalkozik, hogy jelzéseket adjon e téma köréböl, elméleti és gyakorlati problémákat vessen fel, a szintézis igénye nélkül." (Zrinszky, 1988.). 1988-ban tehát, bár voltak kutatók, akik foglalkoztak a témával (Szathmáry, Hajdú, Zrinszky), mégsem alakult ki olyan szakirodalom, melyre a rendszerváltás elött támaszkodhatott volna a szakma. A válasz másik része is ide kapcsolódik: megállapítható ugyanis, hogy ilyen tudományos igényü szakirodalom - melynek hiányát jelezte Zrinszky azóta sem jött létre. Ezt mi sem bizonyítja jobban, mint Zrinszky 1995-ben megjelent munkája, melyben túlnyomó többségben 1988-ban leírt gondolatait olvashatjuk újra.

A bevezetőben bemutatott Kiss által összeállított lista tehát sokkal egyértelmübb, kiforrottabb, pontosabb, mint a különböző müvekben megjelenő szerzőnként összegyüjthető szempontsor. Ami azonban a két lista összehasonlításából ugyanilyen fontos megállapítás az az, hogy Kiss a szociológusok szempontjából vizsgálja a szakmai etikát, így kiváló példát nyújt arra, hogy mennyire gyümölcsöző lehet a pedagógus szakmákkal - a már előzőekben említett szempontok alapján - hasonlóságot mutató szakmák etikai kódexeinek és azok szakmai etikájának a vizsgálata. Érdemes lenne továbbá megvizsgálni ezeknek az etikáknak az elméleti hátterét, kiindulási pontját, valamint fejlődésüket addig a pontig, amíg írásos formát nem nyertek egy kódex keretében.

\section{Irodalom}

Bábosik Zoltán (2001): Értékközvetítés napjainkban. Új Pedagógiai Szemle, 12. sz. 3-10.

Bertók Rózsa (2009): Pedagógusetika - Tanulmányok az oktatás köréből. Ethosz kiadó, Pécs.

Gábor István (1998): Pedagógusmagatartás, pedagógusetika a gyakorlatban. Oktatáskutató Intézet, Budapest.

Hajdú Péter (1986): A pedagógiai etika alapkérdései. Etika pedagógusoknak. ELTE Tanárképző Főiskolai Kar, Budapest.

Hoffman Rózsa (1997): Pedagógusetika - kódex és kommentár. Nemzeti Tankönyvkiadó, Budapest.

Hoffman Rózsa (2003): Szakmai Etikai Kódex Pedagógusoknak. Tanulmányok, normák és esetleirások. Nemzeti Tankönyvkiadó, Budapest.

Kiss Gabriella: Szakmai etika, Szöveggyüjtemény szociológusoknak. URL: http://szoctanszek. unideb.hu/tart/downloads/konyv/szakmaietika.pdf Letöltés ideje: 2014. december 11.

Szathmáry Lajos (1975): Hivatásunk etikai kérdései. Köznevelés, 31. sz.

Zrinszky László (1988): Pedagógusetika a változó világban. Oktatáskutató Intézet, Budapest. 